\title{
Psikoterapide Direnci Anlamak ve Dirençle Çalışmak
}

\section{Ezgi Tuna*}

Orta Doğu Teknik Üniversitesi

\begin{abstract}
Özet
Farklı terapi yaklaşımlarına göre tanımı değişen bir terim o lan direnç, kısaca psikoterapide deği-şime yönelik bir karşı 1 ı kma olarak tanımlanabilir. Her terapi sürecinin bir gerçeği olması ve te-rap inin sonucunu etkile mesi sebebiyle direnci anlamak önemlidir. Geleneksel olarak direnç, danışana ait bir özellik olarak görülür ve tedaviyi engelleyen bir faktöro larak kabul edilir. Buna rağ men, direncin son dönemdeki kavra msallaştırma ları onu danışanın bir özelliği olmaktan çıkarıp terapist ve danışanın ortak şekilde katkıda bulunduğu ve terapi süresince devam eden bir süreç olarak tanımlamaktadır. Ayrıca, direncin tedaviye bir engel teşkil ettiği yönündeki inanışın g iderek değiştiğive direncin vaka formülasyonu ve danışana göre şekillendirilmiş terapötik mü-dahale leri planlamada kullanılabilecek önemli bir bilgi kaynağı olduğu yönündeki fikrin yaygınlaştığı görülmektedir. Bu makalede, direncin kavramsallaştırılması ve psikoterapide di-rençle nasıl çalışılabileceği bir vaka örneğinden yola çıkılarak anlatılacaktır. Bu vakayla yürütü-len psikoterapi çalışmasına dayanarak yazar, direncin bu süreçteki kaynaklarını ve tedavi amaç-larına ulaşmayı kolaylaştırmak için kullandığı müdahaleleri tartışacaktır.
\end{abstract}

Anahtarkelimeler: direnç, psikoterapi, vaka örn eği

*İletişim: ezgi.tuna@yahoo.com

Gönderim Tarihi: 05.07.2016

Kabul Tarihi: 23.10.2016 


\section{Psikoterapide Direnci Anlamak ve Dirençle Çalışmak}

Yirmi bir yaşında bir üniversite öğrencisi olan Berke, üniversite sağlk merkezi tarafindan klinik psikoloji ünitemize yönlendirilmişti. Berke'nin başvuru sebebi son aylarda artan ve okul performansının yanı sıra "okuma, sanat, politika gibi entelektüel aktivitelerinde" de bir bozulmaya yol açan dikkat problemiydi. Danışan yeterince kitap okuyamadığını, okuduğunda ise bir süre sonra okuduğunu anlamadığını, smavlarda gerekli formülleri hatrrlamasına rağmen küçük ayrıntılara takılarak şüpheye düştüğünü ve boş kâğt vererek bazı smavlardan çıktığını ifade etmişti. Terapiden beklentisi "kendini öğrenme amaçlarına daha iyi adamak" olan Berke, söz konusu şikâyetlerinin tamamen çözüme kavuşmasını beklemediğini, çünkü her konuda dışsal etkenlerden kaynaklanan bir "hata payı" olabileceğini dile getirmişti. İlk görüşmemizde, son derece ciddi yüz ifadesi, yaşına göre olgun tavırları ve tok ses tonu ile dikkati çeken Berke, aşırı derece rasyonel ve bağımsız görünmekteydi ve duygu ifadesi çok azdı. Bu haliyle terapiye gelen bir danışandan çok bir gazeteye röportaj veren daha yaşlı bir kişiyi andırmaktaydı. İlerleyen görüşmelerdeki gözlemlerim de ilk görüşmedekinden pek farklı değildi. Berke'nin duygularına, kişisel deneyimlerine ve duygusal skkıntılarına ulaşmak için sorduğum sorular Berke tarafindan hılıca insanlik, felsefe ve hayat prensipleri ile ilgili bir dersle cevaplanmaktaydı.

$\mathrm{O}$ günlerde henüz ilk seanslarını yapan bir terapist olarak grup süpervizyonlarında Berke için "dirençli” dediğimi ve dürüst olmak gerekirse, ona yardımcı olabileceğgimden kuşku duyduğumu hatırlıyorum. Bugün, Berke'yle yürüttüğümüz iki yıla yakın çalş̧maya dönüp baktığımda aklıma çeşitli sorular geliyor: Berke'yi başlangıçta hangi sebeplerle "dirençli" olarak tanımlamıştım? Bu "direnç" öngördüğüm gibi terapi sürecine bir engel oluşturdu mu? Hangi müdahaleler bu sürece yardımcı oldu, hangileri ise olmadı? Bu makalede, bu gibi sorulara cevap arayarak Berke'nin tedavi sürecini örnek olarak kullanıp direncin kaynaklarını ve dirençle çalışırken kullandığım müdahaleleri anlatacağım. $\mathrm{Bu}$ analize temel oluşturması için öncelikle direnci tanımlayacak, kısaca farklı teorik modellerden bahsedecek, direncin kavramsallaştırmasında yaşanan değişimleri özetledikten sonra vaka tartışmasına geçeceğim.

\section{Direnç Nedir?}

Direnç kavramının kökeni psikodinamik geleneğe dayanır (Mitchell \& Black, 1995; Watson, 2006). Freud'un psikodinamik terapi uygularken fark ettiği ilk şeylerden biri danışanda tekrarlayıcı biçimde ortaya çıkan ve psikoterapi çalışmasına karşı duran bir gücün varlığıdır (Yalom, 1980). Direnci tanımlamak ise kolay bir iş değild ir; çünkü yapacağımız tanım, teorik yaklaşımımıza sıkı şekilde bağlıdır (Newman, 2002; Turkat \& Meyer, 1982). Örnek olarak, davranışçı yaklaşımla çalşan bir terapist direnci yönergelere uymama şeklinde tanımlayabilecekken (Leahy, 2003), psikodinamik bakış açısıyla direnç, aktarıma yönelik bir savunma anlamına gelebilir (Schlesinger, 1982). Bunun yanında, direnç terapist olarak danışandan beklentilerimizin neler olduğu ile de oldukça ilintilidir (Leahy, 2003). Beklentilerimize bağlı olarak (ki bunlar da teorik yaklaşımımızla şekillenir), bir psikoterapi sürecinde direnç olarak görülen bir davranış (örn., duygular hakkında az konuşmak), başka bir tedavi kapsamında direnç olarak kabul edilmeyebilir (Leahy, 2003; Turkat \& Meyer, 1982).

Teorik farklılıklara rağmen, çoğumuz dirençle ne kast edildiğini biliriz. Bunun sebebi büyük ölçüde, yaklaşımımız ne olursa olsun direncin terapide var olduğu gerçeği ile ilgilidir. Bariz örnekler arasında danışanın uzun süren sessizliği veya seanslara gelmemesi sayılabilir. Basitçe direnç, "değişime karşı koymak”tır (Basch, 1982, s. 3). Aslında direnç tedaviyi bölen bir olay olmaktan çok, terapi boyunca devam eden bir süreç olarak görülür (Schlesinger, 1982; Wachtel, 1982). Diyebiliriz ki psikoterapide direnç hep vardır (Patterson, 2000) ve danışandan çeşitli beklentileri olan bir terapist var olduğu sürece, direncin var olması kaçınılmazdır (King, 1992). 


\section{Teorik Modellere Bakış}

Literatüre baktığımızda, psikoterapi teorilerinin sayısı kadar direnç modeline rastlamak mümkündür. $\mathrm{Bu}$ sebeple bütün bu modelleri anlatmak bu makalenin amacı dışında görünmektedir. Yine de, bazı önemli yaklaşımların direnci ele alı̧ biçiminden bahsetmek, genel bir bakış açısı oluşturmak açısından önemlidir.

1900ler'in başında direnç kavramını ilk olarak kullanan psikanalitik model (Watson, 2006), danışanları terapiye getiren yüzeydeki sorunların esas sorunlar değil, danışanın içsel çatışmalarının bir temsili olduğunu öne sürmüş ve bu çatş̧malar ilkel biçimde ortaya çiktığı takdirde danışana fazlaca yoğun ve kaygı uyandırıcı geleceğini söylemiştir (Leahy, 2003). Bu gibi durumlarda direnç, söz konusu kaygı uyandıran bilinçdışı materyalin bilinç düzeyine ulaşmasını engelleyici bir işleve sahiptir. Freud'un en önemli gözlemlerinden biri, direncin terapiye bir engel olmadığı, bilhassa terapinin odak noktası olduğudur (Mitchell \& Black, 1995). Psikanalitik psikoterapi, aktarımdaki dirençle çalışmayı ve danışanın erken dönem çatışmalara gerilemesini (regression) içerir (Leahy, 2003). Bilinç dı̧s ve bilinç düzeyindeki direnci yorumlayan analist, danışanın derindeki savunma mekanizmalarını açığa çıkarır ve güçlerini azaltmaya yardme1 olur (Lorand, 1967).

Psikanalitik modelin üzerine inşa olan Adlerci bakış açısı da direnci her klinik durumun bir gerçeği olarak kabul eder ve direncin koruyucu ve uyumsal (adaptive) işlevini vurgular (Watson, 2006). Bu yönelime göre, direnç birbiriyle etkileşen birkaç faktörün sonucu oluşur (King, 1992). İlk olarak, danışan davranışları, semptomlar biçiminde de olsa danışanın kendi bakış açısıyla ve durumuyla tutarlıdır. Koşullar düşünüldüğünde danışan, elinden gelenin en iyisini yapmaktadır. İkinci olarak, direncin bir işlevi de bireysel sorumluluktan kaçınarak özgüveni korumaktadır (King, 1992). Son olarak direnç, danışan ve terapistin terapi amaçları ve ihtiyaçlar konusunda anlaşmazlık içinde olmalarıyla ilişkili olabilir.

Davranışçlar ise genellikle direnci ödevleri veya seanslar arasındaki görevleri tamamlamama gibi biçimlerde görülen tedaviye uyum göstermeme olarak ele alırlar (Leahy, 2003; Turkat \& Meyer, 1982). Söz konusu uyum göstermeme öğrenme ve pekiştirme modellerini kullanarak açıklanır. Bu bakış açısına göre dirence sıç̧a katkıda bulunan faktörler danışanın beceri eksikliği, pekiştireç koşulları (örn., uygun olmayan pekiştireçler) ve terapist ile danışan arasındaki hedef uyuşmazlığıdır (Turkat \& Meyer, 1982). Tedaviye uyumu arttırmak için kullanılan pek çok tekniğe örnek olarak şekillendirme (shaping) verilebilir. Örneğin terapiye uyum göstermeme, hedefleri çok yüksek tutmaktan kaynaklanıyorsa küçük davranışsal hedefler planlanarak her adım uygun pekiştireçlerle ödüllendirilebilir (Leahy, 2003).

Son olarak bilişsel yaklaşım, irrasyonel inançları direncin kaynağı olarak görür (Burns, 1999; Ellis, 2002; Leahy, 2003). Danışanların terapi ve değişimin nasıl gerçekleşeceği ile ilgili atıfları direnci belirleyen en önemli faktörlerdir (Meichenbaum \& Gilmore, 1982). Buna göre, tedaviye uyum dirence değil, danışanın direnç konusundaki düşüncelerine bağıdır (Meichen-baum \& Gilmore, 1982). Danışanların “değişmek çok zor" benzeri inançları işlevsel olmasa da, bu tür düşünceleri değiştirmeleri kolay değildir (Ellis, 2002). Bilişsel terapi uygulayan terapistler danışanı terapiye daha iyi adapte edebilmek için psikoeğitim, irrasyonel düşüncelerin sorgulanması, işbirliğini arttırma, değişimin getiri ve götürülerinin belirlenmesi gibi yöntemlerden yararlanırlar (Newman, 2002).

\section{Direncin Kavramsallaştırılmasında Yaşanan Değişimler}

Geleneksel bakış açısı direnci danışandan kaynaklanan bir süreç olarak konumlandırmaktaydı (Safran \& Muran, 2000). Yani direnç dendiğinde, danışanın yardım almaya, iç-görü kazanmaya ya da terapide ilerlemeye olan direnci akla gelirdi (Silverberg, 1990). Psikanaliz literatürünün genelinde yaşanan, tek kişiye odaklanan bakış açısının daha ilişkisel ve iki kişiye odaklanan bir bakışa doğru evirilmesi 
durumu, zaman içinde direncin yorumlanışını da etkiledi (Safran \& Muran, 2000). Direnç zamanla tek başına danışandan kaynaklanan değil, terapistin ve terapötik ilişkinin de katkı sunduğu bir süreç olarak kavramsallaştırılmaya başland. Bu ilişk iselliği ve etkileşimi vurgulayan Butler ve Bird (2000), direnci "terapist-danışan mücadelesi" şeklinde tanımlamış ve dirençli danışan kavramının "doğrusal, suçlayıcı ve hiyerarşik" olduğunu öne sürmüştür (s. 123). Bugün, hala bazı klinisyenler direnci danışandan temellenen bir kavram gibi görmekte ve müdahaleler işe yaramadığında danışanı sorumlu tutmaktadır (örn., "İyileşmek istemiyor", "Çok dirençli"). Bu geleneksel bakış oldukça basittir ve dirence katkı sunabilecek danışan özellik lerini (örn., danışanın geçmişi, inançları) hesaba katmaz. Ayrıca, tek kişiye odaklanan bu bakış, terapistlerin dirence katkılarını araştırmalarına ve terapi sürecine fayda sağlamayan kendi duyguları üzerine çalışmalarına engel olabilir (Newman, 1994). Dryden ve Neeman (2011) terapistleri terapötik işbirliğindeki sorunları incelerken suçu danışanda arama konusunda uyarmış; terapistlerin dirence kendi katkılarının farkında olmayabileceklerini ve bunu araştırmaya isteksiz olabileceklerini söylemiştir. Öyle ki, danışanı "zor" olarak tanımladığımız birçok durumda bu zorluk, danışanda yatan bir özellik olmaktan öte, terapistin deneyimsizlik ve-ya kendi duygusal meseleleri sebebiyle danışanla çalışmakta yaşadığı zorluktur (Lazarus \& Fay, 1982; Wessler, Hankin, \& Stern, 2001).

Değişim yaşanan bir diğer konu ise direncin olumsuz bir süreç olduğu görüşüyle ilgilidir. Erken dönemdeki kavramsallaştırılmasında direnç, aşıması gereken bir engel olarak görülmekteydi. Freud ilk çalışmalarında direnci bilinçdışı materyali anlama yolundaki bir set olarak kavramsallaştırmıştı (Patterson, 2000; Safran \& Muran, 2000). Sonrasında yapısal modelin geliştirilmesiyle Freud, direnci içsel çatışmaların yarattığ1 tehdide verilen bir tepki olarak görmeye başladı (Safran \& Muran, 2000). Bu bakışa göre direnç, danışan dinamikleri ve aktarım gibi araştrılmaya ve yorumlanmaya değer bir kavram haline geldi (Patterson, 2000). Adler gibi diğer teorisyenlerin katkılarıyla, direncin kurtulmamız gereken bir şey olduğu inancı değişti; direnci araştırmak ve anlamak önem kazandı (Safran \& Muran, 2000). Direnci anlamaya çalışmak önemliydi çünkü direnç skklığı ve derecesi farkhı olsa bile bütün klinik ortamlarda vardı ve bütün danışanlar terapiye bir çeşit karşı tepki göstermekteydi; diğer bir deyişle direncin olmadığı bir danışmanlık ortamı düşünülemezdi. Başka bir önemli nokta olarak da direnç, tedavi sonucunu etkilemekteydi (Otani, 1989).

Direnci olumsuz nitelendiren görüşün aksine, günümüz bakış açısıyla, aslında direnç olarak tanımladığımız davranışların (klinisyen olarak bize işlevsiz gibi görünseler de) danışanlar için bazı işlevleri yerine getiriyor olabileceği düşünülebilir (Dewald, 1982). Silverberg (1990)'e göre danışanları "dirençli" olarak tanımlamak ve değiştirmeye çalışmak, onlardan atılgan olmaları yönündeki beklentimizle çelişmektedir. Bazı durumlarda direnç dediğimiz şey danışanın kendi ihtiyaçlarının peşinden gitmesi ve terapistten bağımsızlı̆̆ını koruma çabası olabilir. Dolayısıyla direnç, danışana öz-yeterliliğini ve özetkinliğini gösterme imkânını sağlayan bir yapı olabilir (Messer, 2002). Bunun yanında direnç, danışanın zorlandığı durumlarda çatışmaları çözme biçimi olarak devreye girebilir. Örneğin, diğer ifade ve çözüm biçimleri danışana kaygı uyandırıcı ya da yabancı geldiğinde, direnç danışanın içsel çatışmaları çözmede kullandığı en iyi ve işlevsel yol olabilir (Dewald, 1982). Bischoff ve Tracey (1995), direnci tedaviye uyum göstermeme şeklinde yorumlamanın eksikliğine işaret ederek, direncin çoğu zaman sınırları korumak gibi sağlklı bir işlevselliğin sonucu olduğunu söyler. Örnek verecek olursak, terapistin yorumu danışanın deneyimine uymadığında danışanın itiraz etmesi oldukça sağliklı kabul edilir (Ellis, 2002).

Özetle, direncin danışanın olumsuz bir özelliği olmadığını, hem terapist hem de danışanın katkısına açık bir olgu olduğunu ve terapistin dirence kendi katkısını araştırmasının büyük önem taşıdı̆̆ını söyleyebiliriz. Ayrıca, tarihsel olarak öyle çağrıştırsa da, direnç istenmeyen ve olumsuz bir şey olmak zorunda değildir. Gerçekte direnç önemli bir bilgi kaynağıdır ve danışan için uyumsal (adaptive) bir strateji olabilir. Dolayısıyla terapistin direnci, kullandığı yaklaşımdan yola çıkarak anlamaya çalsşması terapi çalısmasına önemli bir bilgi aktarımı sağlayabilir. 


\section{Vaka Örneği}

Berke'nin psikoterapi sürecinde direncin tartş̧ılmasına geçmeden önce, danışanın sorunları, arka planı ve psikoterapi çalışmasının ana hatlarından bahsetmek bilgilendirici olacaktır. Berke işçi sınıfı, dini azınlık mensubu bir ailenin tek çocuğudur ve fen bilimleri bölümlerinden birinde öğrencidir. Berke’yi terapiye getiren temel sebep dikkat problemi diye tanımladığı, snavlarda doğru cevapları hatrlayamaması ve odaklanmakta yaşadığı zorluk sebebiyle okul başarısında yaşadığı düşüştür. Berke'nin buna verdiği tepki kendisini takıntılı biçimde cevabı hatırlamaya zorlamak ve hatıllayamazsa smavı terk etmek şeklindedir. Danışanın oldukça yoğun bir ders programı vardır, boş zamanlarını ise okuyarak, şïr yazarak, öğrenci kulüplerinde oyunculuk yaparak ve karikatür çizerek geçirmektedir. Terapiye başladığında danışan bir sömestrde 8 ders almakta, gün içinde okuması "gereken" kitaplarla dolu ağır bir çantayla okula gitmekte, uyku süresini 5 saate indirmeye çabalamaktayd. Berke hayatının dürüstlük, samimiyet, tutarlılı gibi ilkeler doğrultusunda şekillendiğini söylemekteydi. Örneğin samimi bulmadığı için bir ortamda karşılaştığı insanlarla havadan sudan konuşmamakta, bunun yerine susmayı tercih etmekteydi. Aşırı bir sorumluluk hissi vard1; dünyadaki açlk, kuraklkk gibi trajediler karşısında kendisini suçlu ve çaresiz hissetmekteydi. Politikayla ilgileniyordu ve sık sk kampüsteki protestolara katılmaktayd1. Hep parlak bir öğrenci olmuştu fakat babasının kendisinden daha fazlasını beklediğini ve performansını eleştirdiğini söylemekteydi.

Danışan babasını hafta sonları bile çalışan mükemmeliyetçi bir kişi olarak tanımlamış, babasının dürüstlüğ̈ takıntı derecesinde ilke edindiğini ve küçüklügünde Berke'nin yalanını yakaladığında dürüstlükle ilgili öğütler verdiğini söylemişti. Fakat babasının yalnızca alkol almadığı zamanlarda sarsılmaz ve güvenilir olduğunu, dolayısıyla dürüstlüğü babasına göre bir adım öne taşıdığını belirtmişti. Babası Berke'nin çocukluğunda dönem dönem işsiz kalmıştı ve aile bu dönemlerde maddi sıkıntılar yaşamıştı. Çocukluğunda Berke, faturaları ve kiranın ödenip ödenmediğini takip ettiğini ve ailenin maddi birikimlerinin kendi odasında saklandığını hatırlamaktaydı. Berke'nin babasının uzun yıllardır süren alkol problemi vardı, haftanın birçok günü eve geç gelmekte, sesini yükseltmekte ve Berke'yi uyandırmaktaydı. Berke bu durumu öngörülemez, samimiyetsiz ve babasının aylk haliyle tutarsı bulduğunu, böyle durumlarda babasına yaptığının yanlış olduğunu göstermek için onunla konuşmadığını ve onu yok saydığını söylemişti. Bir çocukluk anısında Berke, annesinin hastalandığı bir gece babası sarhoş olduğu için kendi başına ambülans çağırdığını ve hastanede evrak işlerini hallettiğini hatırlamaktaydı. Danışan annesine duygusal olarak daha yakındı. Anne ve babasını evliliklerinin maddi bir ortaklığa benzediğini söyleyen Berke, anne babasının tartışmaları sırasında araya girdiğini, onları farkhı odalara götürerek sakinleştirdiğini ifade etmişti. Bu bilgiler bana Berke'nin babasmın alkol probleminin de etkisiyle duygusal olarak stabil olmayan bir ortamda büyüdüğünü ve erken yaşta aile içinde bir ebeveyn rolü üstlendiğini düşündürmüştü.

Berke'nin babası Berke'nin aldığı kararlarda hep çok etkili olmuştu. Sosyal bilimlere merakı olduğu halde fen bilimlerinden bir bölümü seçen danışan, kendisini anlamaması ve yönlendirmesi sebebiyle babasını suçlamaktayd1. Çocukluğundan beri "çok bilen, ukala" olarak tanımlandığını söyleyen Berke, yaşı küçük olduğu için ciddiye alınmadığını belirtmişti. Üniversiteye başladığından beri daha bağımsız hisseden Berke, babasıyla politika gibi konularda daha sk zitlaşmaktaydı. Anne ve babasının popüler ve siradan zevkleri olduğundan yakınan danışan, onların sanat zevklerini şekillendirmeye çalışığını belirtmişti.

Berke'nin üniversite merkezli bir arkadaş ağı vardı ve kendisini ilişkilerde "yüzde yüz samimiyete inanan, hümanist bir kişı”’ olarak tanımlamaktaydı. Buna rağmen arkadaşlarının kendisini yanlış anlayacaklarını ve yadırgayacaklarını düşünmekte; bunun sonucunda insanlarla birlikteyken spontane olamamakta ve olası yanlı̧s anlamaları önlemeye çalş̧maktaydı. Daha önce hiç romantik ilişkisi olmamıştı ve olursa bunun normal arkadaşlıktan nasıl farklı olacağını bilmediğini söylemişti.

Psikoterapi sürecinin ilerleyişine bakacak olursak, başlangıçta Berke'nin önceliği dikkat problemlerine odaklanmak ve bunların kaynağını anlamak olmuştu. Bu aşamada, çalışmalarıyla ilgili katı 
kuralları, kendisinden mükemmeliyetçi beklentileri ve bir dizi katı ahlaki ilkesi olduğu belirlendi. Bu kural ve ilkelerin nasıl oluştuğu, işlevleri ve hayatı üzerindeki etkileri araştırıldı. Ayrıca zaman zaman arkadaşları ve ailesinden de söz eden Berke'nin sosyal durumlarda nasıl değerlendirildiği ile ilgili yoğun bir kaygı yaşadığı ve özellikle yanlış anlaşılmakla ilgili korkuları olduğu belirlendi. Berke ilişkilerinde daha rahat olmak ve içinden geldiği gibi davranabilmek istiyordu. İlişkilerde de samimiyet, yakınlık ve birbirini anlama ile ilgili bazı genellemeleri ve katı kuralları olduğu tespit edildi. Bunun üzerine sosyal ilişkilerde yaşadığı kaygiyı anlamak ve azaltmak bir başka terapi hedefi olarak belirlendi. Sonraki aylarda, ilişkilere dair kural ve inançları saptand, bunların ne kadar gerçeğe uygun ve işlevsel oldukları, ve ilişkileri üzerindeki etkileri araştırıldı. Kaygiyı telafi etmek amacıyla kendisini açmaktan uzak durma, soyut ve duygusallıktan uzak konular hakkında konuşma, yanlış anlaşılmayı önlemek uzun açıklamalar yapma gibi bazı yöntemler kullandığı belirlendi. Bunun üzerine, ilişkilerinde kendisiyle ilgili paylaşımlarını, spontanlığı ve duygu paylaşımını arttırması üzerine çalışıldı. Buna paralel olarak, kendi duygularının farkına varması ve bu duyguların nasıl oluştuğunu anlaması konularında da yol alındı.

\section{Direncin Kavramsallaştırılması}

Direnç birçok farkh şekilde ortaya çıktığı gibi, birçok farklı amaca da hizmet edebilir (Messer, 2002). Yukarıda da belirtildiği üzere, direnci nasıl tanımladığımız ve kavramsallaştırdığımız büyük ölçüde teorik duruşumuza ve danışandan beklentilerimize göre şekillenir. Ben eğitimi ağırlkklı olarak Bilişsel Davranış̧̧ı Terapi yönelimli bir terapist olarak danışanların ihtiyaçlarına uygun olarak şekille ndirdiğim ve danışanları daha bütüncül ve zengin bir bakış açısıyla ele almamı sağlayan eklektik bir yaklaşım kullanmaktayım. Uyguladığım temel terapi yöntemi bilişsel davranışçı terapi olmasına rağmen, Berke ile yürüttüğümüz psikoterapi çalışmasında danışanın kavramsallaştırmasında ve bazı şikayetlerin çözümlenmesinde bilişsel davranış̧̧ı yönteme katkıda bulunduğuna inandığım içgörü ve ilişki odaklı bir terapi yaklaşımı olan psikodinamik yaklaşımın teori ve tekniklerini terapötik çalş̧mama entegre ettim. $\mathrm{Bu}$ şekilde terapistin temel psikoterapi yaklaşımını koruyarak, bununla uyum sağlayan ve terapi sonucuna anlamlı bir katkı sağlayabilecek farklı terapi yaklaşımlarından teori ve teknikleri esas yaklaşımın eksiklerini giderecek şekilde kullanmasına asimilatif bütünleştirme (assimilative integration) denmektedir (Lampropoulos, 2001). Dolayısıyla, uyguladığım terapötik yaklaşımda temel olarak bilişsel davranışçı yaklaşımdan yola çıkarak Berke'nin çarpitılmış düşünce, kural ve inançlarının saptanması, bunların ortaya çkardığı duyguların tespit edilmesi, bilişsel yeniden yapılandırma ve imgeleme gibi teknikler kullandım. Bu yaklaşıma ise özellikle terapideki direnci ve terapötik ilişkiyi anlama açısından katkıda bulunduğuna inandığım psikodinamik teoriyi entegre ettim. Bu yaklaşıma uyumlu biçimde Berke'den terapist olarak beklentilerim arasında öne çıkanlar, olaylar karşısındaki düşünce ve duygularının saptanması, çocukluk yaşantıları ve aile ilişkileri gibi geçmişten gelen konuların araştırılması ve bugünkü davranış örüntüleriyle bağdaştırılması, tekrarlayıcı düşünme ve ilişki kurma biçimlerinin anlaşılması gibi konularda benimle işbirliği içinde olmasıydı. Şimdi, direnç bağlamında bu beklentilerimin terapide nasıl karşılı bulduğuna bakalım.

Danışanların terapideki davranış biçimleri terapi dışındaki tepkileriyle benzerlik gösterir (Engle \& Holiman, 2002). Buna dayanarak, Dryden ve Neenan (2011) danışanların kişilerarası ilişki biçimlerinin terapi çalışmasındaki dirence katkıda bulunabileceğini söylemiştir. Berke'ye sorduğum en basit görünen sorulara bile duygusal içeriği olmayan, uzun, genellenmiş ve soyut cevaplar almaktaydım. Berke entelektüel konuşma biçimini çok sık kullanmaktaydı; bu stil danışanın kasıth ve tekrarlayıcı biçimde teknik bir dil ve soyut kavramlar kullanması şeklinde tanımlanabilir (Otani, 1989). Aşırı derece entelektüel kişilerarası ilişki tarzı olan danışanlar duy-guları hakkında konuşmaktan kaçmabileceği gibi, sorunlarını oldukça rasyonel biçimde açıklayabilirler. Bu tarzın entellektüelizasyon savunma mekanizmasıyla benzerliğini fark edebilirsiniz. Entellektüelizasyon kişinin hoşa gitmeyen duygulardan kaçınmak amacıyla, duygu ve 
dürtüleri kontrol etmek için genelleştirme ve soyutlamalar kullanması şeklinde tanımlanabilir (Zepf, 2011). Bu mekanizmayı kullanan danışanlar duygularının varlığını kabul etseler bile, içsel deneyimleri hakkında tipkı bir hava durumu raporu okuyormuşçasına konuşurlar (McWilliams, 1994). Söz konusu soyutlamaların duyguyu yalıtarak, içgüdüsel istekleri bilinçten uzak tutma işlevi gördüğüne inanılmaktadır (Zepf, 2011).

Berke'nin entelektüel kaynaklarını, soyutlamaları ve genelleştirmeyi bir savunma olarak kullanmasına birçok örnek verilebilir. Örneğin bir görüşmemizde, Berke'nin sosyal ilişkilerde spontane olamaması ve konuşmanın akışıı kontrol etme çabası hakkında konuşmaktaydık. Ben olumsuz beklentilerini ve duygularını anlamaya çalışrken Berke odağımızı dil felsefesine olan ilgisine, dilin işlevine ve manipüle edici özelliğine çevirdi. Başka bir seansta cinsellikle ilgili konuştuğumuzda, porno endüstrisini cinsiyet çalışmaları jargonuyla eleştirmeye başladı. Tahmin ediyorum ki bu tarz, sosyal ilişkilerinde de benzerdi; Berke arkadaşlarıyla şïr, politika gibi konularda uzun sohbetler ettiklerinden bahsediyor, fakat kendiyle ilgili çok az şey paylaşıyordu. Düşünce ve deneyimlerini soyut kavramlarla anlattıkça Berke, içsel deneyimlerinden ve psikolojik dünyasından uzaklaşarak daha genel, soyut; fakat güvenli bir alana doğru kaymaktayd 1.

Messer (2002) direncin bir biçimi olarak danışanın dürtü, duygu, fantezi ve güdülerini tanımaya yönelik direnci' nden söz etmiştir. Berke'nin entellektüelizasyonunun bir işlevi de bu kaygı uyandırıcı duygu ve arzuları engellemek olabilirdi. Messer (2002)'e göre, danışanlar olumsuz duyguların (özellikle kaygının) açığa çıkma ihtimali sebebiyle bu alanları göstermekten uzak dururlar ve bu kaçınma terapist tarafindan ele alımmalıdır. Berke terapide uzun süre istenmeyen ve utanç verici bulduğu öfke ve cinsellik gibi konuları konuşmaktan uzak durmuştu. Ona göre, bu dürtü, duygu ve fantezileri kabul etmek ve anlatmak oldukça zordu. Öfkesini, saldırgan dürtülerini ve fiziksel ihtiyaçlarını reddediyordu ve eğer bunlara izin verirse, bu dürtülerin kendisini tamamen esir alacağından korkuyordu. Fiziksel ihtiyaçlarını ve duyguları zayıflık olarak tanımlayan Berke, bunların kontrol altında tutulmadığ 1 takdirde kendisine ve başkalarına zarar vereceğine inanıyordu. Örneğin, olumsuz bir yaşantıya verdiği tepkiler hakkında konuşurken otomatik şekilde "Ama öfkelenmedim" diyor ve öfkelenmeye hakkı olmadığını; bir katile bile kızamayacağını çünkü onun bile kötü bir insan olmak amacıyla yaşamadığını söylüyordu. Buna rağmen, protestolar esnasında polis memurlarına zarar verme fantezileri vardı ve öfkelendiği takdirde kontrolünü kaybetmekten korkuyordu. Berke için terapiste olan duygularını dile getirmek de zordu. Diğer duygular arasında, özellikle terapiste karşı öfkenin bastırılması aktarımda en sık yaşanan dirençlerden biri kabul edilir (Messer, 2002). Bu tür bir direnç, danışanın terapistten bir karşı saldırı geleceğine yönelik endişesiyle ilişkili olabilir (Messer, 2002). Berke terapi süresince, bana karşı olumsuz duygularını dile getirmekten uzak durdu. Bazı seanslarda ses tonu ve duruşu öfkelendiğini yansitsa da bunu sözel olarak dile getirmedi ve yapılan yüzleştirmeleri de uzun süre reddetti. Bunlara ek olarak Berke, terapide uzun süre cinsellikle ilgili konuları paylaşmadı. Terapist konuya değindiğinde ise bu gibi şeyleri terapide konuşabileceğini bilmediğini ifade etti. Berke cinsellikle ilgili arzularını kontrol edememe endişesi taşıyordu ve cinsel dürtülerini bastırmaya çalş̧maktaydı (“Önlemeye çalşıyorum, keşke cinsel istek gibi bir zayıflığım olmasaydı”). Berke için öfke ve cinsellik gibi bu derece kaygı uyandıran konuları terapide dile getirmek fazla riskli görünüyordu. Berke'nin geçmişi düşünüldüğünde, tıpkı eleştirel ve cezalandırıcı babası gibi terapisti olarak benim de onu dürtüleri ve spontanlığı karşısında kabul etmeyeceğimden ve eleştireceğimden korkmuş olabilirdi.

Leahy (2003)'e göre, birçok danışanın değişime yönelik isteksizliğinin temelinde ahlaki akıl yürütme olabilir. Berke'nin düşüncelerinin çoğu suçluluğun eşlik ettiği ahlaki prensipler ve “-meli, -malı"lar tarafindan yönlendirilmekteydi. Kullandı̆̆ dilde sikça kurallara, görevlere ve zorunluluklara atıfta bulunmaktaydı. Yedinci seansta, yalnızca keyif için yapılacak aktiviteleri gerçekleştirmekten kaçındığını ve bunlara olan ihtiyacından kurtulmaya çalıștığını söylemiş; açlik ve kuraklik gibi durumlarda insanların değerlerini kaybettiğini ve yaptkları her şeyde kendilerini hakl gördüklerini belirtmişti. Berke'nin bu tavrı ahlaksallaştırmanın savunma olarak kullanılmasına örnek oluşturabilir. Bu savunmayı kullanan 
kişiler kararlarını ve davranışlarını, ahla-ki sebeplerden dolayı gerçekleştirilmesi şart olan görevler olarak tanımlarlar (McWilliams, 1994). Ayrıca bu kişiler, kendilerinin aktör olmadığı durumlara yönelik bile aşırı bir sorumluluk hissederler (McWilliams, 1994; Leahy, 2003). Berke dünyadaki insanların ıstrabına yönelik kendini sorumlu hissetmekte ve yardım edemediği için yoğun bir suçluluk hissetmekteydi. İkinci görüşmemizde, kötü geçen bir günün detaylarını sorduğumda Afrika'daki açlik yüzünden kötü hissetmiş olabileceğini söylemiş ve dünyadaki eşitsizlik karşısındaki sorumluluklarımız hakkında konuşmaya başlamıştı. Fark edilebilece ği gibi, bu abartılmış sorumluluk, Berke'nin bir çocuk olarak ailesinde yerine getirmesi gereken ve yaşına uygun olmayan sorumluluklarla paralellik göstermektedir. Berke bu özelliğiyle gurur duysa da, bu savunma kesinlikle terapi çalışmamızı zorlaştırmaktaydı. Kendisini baltalayıcı örüntüleriyle ve hissettiği aşırı sorumlulukla ilgili yaptığım yorum ve yüzleştirmelerde Berke, davranışlarını değer ve prensiplerine bağllyordu.

Yukarıda değindiğim birçok noktada, Berke'nin kullandığg ortak bir savunma olarak yalitma (isolation) öne çıkmaktadır. Yalıtma, düşünceler ve duygular ile kendilik arasındaki bağlantıların tehdit edici bir anlamdan uzaklaşması için kırılması olarak tanımlanabilir (Björklund, 2000; Schlesinger, 1982). Yalitma entellektüelizasyon ve ahlaksallaştırma gibi bilişsel savunmaların temel psikolojik bileşeni olarak kabul edilir (McWilliams, 1994). Çoğu zaman Berke önemli olumsuz olaylarla ilişkili duyguyu yaltmakta ve olayla ilgili anlattıkları soğuk ve mantıklı bir açıklama şeklinde kulağa gelmekteydi. Ayrıca, tetikleyici olaylar, duyguları ve düşünceleri arasındaki bağ çoğu zaman zayıftı; dolayısıyla duygularla ilgili deneyimi onların tahmin edilemez ve durup dururken oluştukları şeklindeydi. Dikkat çekici bir örnek 37. Seansta gerçekleşti. Berke haberlerde izlediği ve kendisinde yoğun duygular uyandıran bir olayı anlattı. Haberde bir baba bütün ailesini öldürerek büyük oğluyla birlikte pencereden atlayıp intihar etmişti. Berke bu olayın kendisiyle bağlantısını anlamamıştı; birlikte anlamını ve bağlantıları araştrdığımızda ilk defa bana annesinin intihar girişiminden bahsetti. Bu olay gerçekleştiğinde haberdeki büyük çocukla aynı yaştaydı. Berke iki olay arasındaki bağlantıyı reddetti, annesinin girişiminin kendisinde iz brrakmadığını, olumsuz bir duygu uyandırmadığını belirtti. Bu, Fenichel (1946)'in "duygunun yer değiştirmesi” diye tanımladığı durumu hatırlatmaktadır: Danışan önemli bir olayı konuşurken soğukkanlı kalır, fakat olayla ilişkili duygu başka bir noktada açığa çıkar. Terapide çahışığımız temel alanlar arasında duygularla çalşmak ve kendini tekrarlayıcı örüntüleri saptamak olduğunu düşünürsek, Berke'nin yalitma savunmasının terapi sürecimizi olumsuz etkilediği aşikardi.

Leahy (2003)'ye göre, danışanların şematik işlemlemeleri kendini terapi ortamında da gösterir ve terapötik ilişkiye engel teşkil edebilir. Kişiye özel bir içeriğe sahip olan şemalar kısaca, bilginin işlemlenmesine sistemli bir yanlılı katan kişiliğin temel parçaları olarak tanımlanabilir (Beck, Freeman, \& Davis, 2004). Örneğin, eğer kişinin reddedilme ile ilgili bir şeması varsa, seçici biçimde reddedildiği durumlara dikkatini yöneltebilir veya nötr bir durumu reddedilme şeklinde anlamlandırabilir. Terapide ortaya çıkan temel bir konu Berke'nin yanlş̧ anlaşılacă̆ı ve cezalandırılacağına yönelik inancıydı. Bu şemayla başa çıkmak amacıyla sosyal durumları saniye saniye analiz etmekte, başkalarından gelecek olumsuz tepkileri ve anlaşılmadığına dair belirtileri tespit etmeye çalışmaktaydı. Ayrıca özellikle yeni tanıştı̆̆ insanlarla doğru kelimeleri seçmeye ve konuşmanın gidişatını kontrol etmeye çalışmakta, kendisini net biçimde ifade etmek için uzun açıklamalarda bulunmaktaydı. Berke çok basit oldukları ve insanların kendisini $100 \%$ anlamalarına engel olacağı gerekçesiyle kategorizasyonlara ve isimlendirilmeye karşı çok hassastı. Bir kadına karşı hissettiği duygulara "hoşlanmak" gibi bir isim takmaktan kaçınıyor ya da insanları tanımlarken çeşitli sıfatlar kullanmanın kişileri o rollere mahkûm etmek anlamına geleceğini söylüyordu. Bunun yanında, Berke'nin baskın, mükemmeliyetçi babasıla ilişkisine ve toplumdaki azınlık pozisyonuna dayandığını düşündüğüm otorite pozisyonundaki kişi ve kurumlarla ilgili (örn., üniversite, hocalar, devlet), olumsuz inançları vardı. Otoritelerin beklentileri karşısında kontrol edilmiş, cezalandırılmış ve bunalmış hissediyor, ve onları kendisini anlamamakla ve kabul etmemekle suçluyordu. Berke'nin altta yatan 
inançlarının bizim ilişkimizde de işlediğini söyleyebiliriz. Bu bakış açısıyla, danışanın yaptı̆̆ ve direnç olarak adlandırılabilecek birçok davranış aslında şemalarının bir yansıması olarak yorumlanabilir. Örneğin, terapide olaylarla ilgili uzun detaylı anlatımları kendisini tam anlamıyla anlatabilme çabasıyla ilgili olabilir. Yorumlarıma ve tekrarlayıcı davranış örüntüleriyle ilgili kategorizasyon çabalarıma olan itirazı kategorize edilmekle ilgili hassasiyeti ve yine yanlış anlaşılma kaygısıyla ilişkili olabilir. Dahası, duygularını ve arzularını terapiste açmaktaki tereddüdü otoritelere yönelik güvensizliğiyle ilgili olabilir; ki terapötik ilişki dahilinde terapist rahatlkkla otorite olarak algilanmaya açıktır. Young, Klosko, ve Weishaar (2003) kişinin kimliğinin önemli parçalarını oluşturan şemaları değiştirmenin zorluğundan bahseder. Bu anlamda direnç, Berke'nin kimliğini korumak ve içsel bir kontrol ve bütünlük oluşturmak için kullandığ bir girişim olarak değerlendirilebilir (Young ve ark., 2003).

\section{Dirençle Çalışmak}

Dirençle çalışma şeklimiz direnci nasıl kavramlaştırdığımızla yakından ilişkilidir (Arkowitz, 2002). Buna rağmen şimdiye kadar farklı teorik modeller arasında direnci yok etmek değil, anlamanın gerekliliğine yönelik bir ortaklık sağlandığını söyleyebiliriz. Direnç danışanın tehdit altında olduğuna işaret edebilir (Schlesinger, 1982). Schlesinger (1982) bunun bir paradoks olduğunu söyler; çünkü danışan terapötik çalışmaya direndiğinde aynı zamanda terapiste araştırılmaya değer bir alan hakkında önemli bir bilgi de sağlamış olur. Newman (1994) da direnci anlamanın sağladığı zengin bilgiden söz eder. Direnci "esas" tedaviye bir engel olarak görmektense, bu bilgiyi vaka formülasyonuna rehberlik edecek, empatiyi güçlendirecek ve müdahaleleri yönlendirecek ş̧ekilde kullanmayı önerir (Newman, 1994). Sonuç olarak, dirençle savaşmak yerine, onu hoş karşlamak mümkün görünmektedir (Schlesinger, 1982).

Berke'nin tedavi sürecinin ilk aşamasında, birçok klinisyen gibi ben de direnci savaşlacak ve yok edilmesi gereken bir engel olarak görmüştüm. Seanslar sirasında ve sonrasında kendimi çikmazda, çaresiz ve kafası karışmış hissettiğim zamanlar oldu. Berke ve ben uyumlu biçimde hareket edemiyorduk; Berke çoğunlukla entelektüel bir noktadan hareket etmekte, söylediğim ve önerdiğim şeylerin çoğuna itiraz etmekte; ben ise karşllk olarak psikoloji bilgimi kullanarak yöntemlerimi savunmaktaydım. Örnek olarak, iki davranış arasındaki benzerliğe yönelik gözlemimi paylaştı̆̆ımda Berke, analoji yapmanın sakıncaları ile ilgili bir savunma yapıyor, ben de cevap olarak tekrarlayan örüntüleri saptamanın öneminden bahsediyordum. Bu durum bende öfke, çaresizlik, engellenmişlik gibi duygular uyandırıyordu. Seanslar ilerlemesine rağmen yol kat edemediğimizi hissediyordum ve bu durum terapist olarak bende yetersizlik hislerini ortaya çıarıyordu. Belli ki bu güç mücadelesinin terapi süreci açısından sağaltıcı bir tarafi yoktu. Silverberg (1990) dirence rağmen danışanlara zorla yardım uygulamaya çalş̧manın ters bir etki yaratabileceğini söyler; ne zaman ki terapist dirence saygı duyar ve onu yok etmekten vazgeçer, danışan da tedaviye daha uyumlu hale gelir. Terapide dönüm noktası o dönemde aldığım süpervizyonda süpervizörümün verdiği geribild irim yardımıyla gerçekleşti. Süpervizörüm Berke ile girdiğim mücadeleye dikkat çekerek, Berke'nin sadece kendisi gibi davrandığını, terapideki davranışlarının bana ve tedaviye yönelik kasttlı bir tepki olmadığını söyledi. Berke'nin seans içindeki davranış örüntüsü onun kendini ortaya koyma biçimydi; süpervizörüm bununla mücadele etmek yerine bilgi verici bir kaynak olarak kullanabileceğimi hatırlattı. Bu geribild irim sayesinde güç mücadelesinden bir adım geri durarak Berke'yi bana ve tedaviye direnen bir kişi yerine, kendisi olmaya çalş̧an ve kimliğiyle tutarlı hareket eden, tehdit altında, fakat dayanıklı bir kişi olarak görmeye başladım. Terapide varoluş şekline bakarak Berke'nin korkularını, baş etme biçimlerini, sosyal ilişkilerde ilişkilenme biçimlerini anlamaya çalışım. Savaşmayı braktı̆̆ımda, ilişkimizin güçlendiğini fark ettim.

Yukarıda bahsettiğim gibi, Berke entelektüel tarzı fazlaca kullanan bir danışandı ve bu tarz, terapi görüş̧melerimize de egemen olmuştu. Dryden ve Neenan (2011) terapist danışanın entelektüel stilini 
pekiştirirse bunun terapötik işbirliğinin kurulmasını zorlaştrabileceğini söyler. Terapinin başlangıcında görüşmelerimizin büyük kısmı soyut kavramların tartışıldığı ve duygulara pek değinilmeyen yuvarlak masa tartısmalarına benzemekteydi. Belirli noktalarda, sıkılmış ve çaresizce, Berke'nin konuşmasını bölerek daha spesifik bir soru sorardım; fakat sanıyorum ki bu müdahale işbirliğine katkı sağlamazd1. Diğer zamanlarda, entelektüel-rasyonel konuşmaya ben de katılır ve Berke'yi daha iyi anlamak için genel, soyut kavramlar hakkında takip soruları sorardım. Rasyonel olmayan düşüncelerin geçerliliğini sorgulamanın (ki bu diğer danışanlarla sklıkla kullandığım bir tekniktir) Berke'yle iyi sonuçlar vermediğini söylemek sürpriz olmaz; çünkü bu sorgulamalar daha fazla soyut tartısmaya yol açıyordu. Sonrasinda fark ettiğim şey şuydu: Onu durdurarak ya da entelektüel diyaloga dâhil olarak onun kişilerarası iletişim tarzını pekiştiriyor ve dirence katkı sağliyordum.

Entelektüel kişilerarası iletişim tarzna sahip danışanlarla çalışmada Dryden ve Yankura (1993; akt. Dryden \& Neenan, 2011) duygu ifadesini arttırmak için duygu temelli teknikleri, terapistin kendini açmasmı ve mizahı önerir. Berke'nin duyguları ve kişisel deneyimlerine daha fazla yer açma konusunda birkaç teknikten fayda sağladım. Öncelikle, haftalar süren kafa karışılığı ve çaresizliğin ardından, Berke'yi mantıklı, entelektüel fakat duyguların olmadığ 1 iletişim stiliyle yüzleştirdim. Yüzleştirme, danışanı durdurur ve onu terapistin tespit ettiği fakat çoğu zaman danışanın farklında olmadığı bir gözleme dikkat vermeye davet eder (Schlesinger, 1982). Berke, tarzı hakkındaki yorumuma itiraz etti ve karşıt delil olarak günlük konuları konuşabildiği arkadaşlarının olduğunu, bazı günler bir güzellik fark edeceği, birini seveceği düşüncesiyle evden çıtığını ve duygulu bir kişi olduğunu belirtti. Peki, eğer bu doğruysa, terapide farkh mı davranıyordu? Bunun üzerine Berke kendini nasıl göstermesi gerektiği ile ilgili kaygılı olduğunu, duygular zayıflık olarak görülebileceği için terapide daha büyük konular hakkmda konuştuğunu ve bunun saçma bir korku olduğunu ifade etti (“Eğer bir kasaptan örnek verseydim gülünebilirdi”). Bu paylaşım esnasında duygulanımında belirgin bir değişiklik olmamıştı ve Berke duygular hakkında genel bir konuşma ile sözlerine devam etti. Danışan sonraki görüşmeye tarzı hakkındaki geribildirimime karşıt başka gözlemlerle geldi. Bu müdahalenin iki şekilde işe yaradığını düşünüyorum: Birincisi, davranışı uzun süre değişmese de Berke kendi iletişim biçimini gözlemlemeye başladı. İkincisi ise, bize Berke'nin altta yatan inançlarıyla ('Duygular zayıflıktır”, "Entelektüel maskesini takmazsam küçümsenebilirim”) ilgili bilgi verdi. Tedavi süreci boyunca çok kere Berke'nin iletşşim stili ile ilgili yüzleştirmeler yaptım. Aramıdaki güven ve işbirliği güçlendikçe Berke gözlemlerime karşı daha açık olmaya başladı. Ardından entelektüel konuşmanın insanlarla sohbete girmeyi kolaylaştırma gibi işlevleri hakkında konuştuk ve ilişkileri üzerindeki etkilerini araştırdık. Güvenilir bir ilişki kurmamızı takiben, Berke'nin entelektüel tarzına yönelik mizah da kullanmaya başladım ve Berke de bu konuda şaka yapmaya başladı ("Size kızmış olsam bile bunu genelleyip psikoloji eleştirisi yapardım"). Mizahın psikoterapi ilişkisini derinleştirme ve terapötik işbirliğini kurma potansiyeli vardır (akt., Sultanoff, 2013). Bizim için mizah, artan uyumumuzun ve yakınlığımızın bir göstergesi haline geldi.

Yardımcı olan bir başka strateji de Berke'nin söylediklerini basitleştirerek, genel ve soyut alandan kişisel alana taşıyarak yaptı̆̆ım çerçevelendirmeler (reframing) oldu. Berke nadiren birinci tekil şahısta konuşurdu. Bunun yerine, insanlardan ve insanlıktan bahseder ya da kendi deneyimlerini tarif ederken edilgen cümle yapısı kullanırdı. Bir görüşmemizde, hocasıyla girdiği bir tartışmadan sonra eğitim sistemini eleştiriyordu. Söylediklerini yeniden çerçevelendirdim ve duygusunu aynalayarak "Hocalar ihtiyaçlarınıza duyarlı davranmadığı için öfkelisiniz" dedim. Bu şekilde odak noktamı genellemelerden uzaklaştı ve ilerleyen seanslarda Berke duygu, düşünce ve davranışlarıyla ilgili daha fazla konuşmaya başladı.

Rasyonel ve entelektüel stili yoğun olarak kullanan Berke'yle duygularla çalısmak tedavinin önemli bir kısmını oluşturdu. Daha önce de bahsettiğim gibi Berke önemli olaylardaki duygularını yalitıyordu ve duygularının günlük durumlar, düşünceler ve davranışlarıyla bağlantısını kurmakta zorlanıyordu. Kırk beşinci görüşmemizde yaptığı gözlem tam olarak bunu yansitıyordu: "Olumsuz olayları izole ediyorum, 
ne geçmişe sıçriyorlar ne de geleceğe”. Burada biraz psikoeğitim kullanmak durum-düşünce-duygu ilişkisini anlatmam açısından işe yaradı. Bunun ardından, duyguların kaynağını araştırmaya başladık. Örneğin smavlarda dikkat probleminden yakındığında, o anki düşüncelerini ("Hatırlamam lazım, unutmak kabul edilemez"), duygularını (kaygı, stres) ve davranışlarını (cevabı hatırlamaya zorlamak, smavı yarıda bırakmak) araştırdık. Böylece, Berke'nin duyguların tahmin edilemez ve tehditkâr olduğu ile ilgili düşünceleri değişmeye başladı.

$\mathrm{Bu}$ süreçte bazı noktalarda kendimle ilgili paylaşımlarda bulundum ve bunun terapötik bir etkisi olduğunu düşünüyorum. Maroda (2010)'ya göre terapistin duygularını paylaşması "danışana kendisini daha açık biçimde görebilmesi ve kendisini diğerlerine göre konumlandırabilmesi konusunda davranışsal bir geribildirim sağlar" (p. 118). Rogers ise terapistin kendini açmasının (self-disclosure) dikkatlice kullanılması gereken bir teknik olduğunu ve ancak terapistin ihtiyaçlarını doyurmak yerine danışanın yararına olacaksa kullanılmasını önerir (Hol-mes, 2005). Kendimi açtığım zamanların çoğunda amacım Berke'ye kendini baltalayan örüntüleriyle ilgili ayna tutmak olmuştu. Örneğin, ilerleyen seanslardan birinde Berke'nin soyut tartışmalarının bizi bir yere götürmediğini fark ettim ve hissettiğim kaybolmuşluk ve kafa karışıklığı duygularını onunla paylaştım. Bunu takiben, söz konusu iletişim biçiminin Berke'nin anlaşılma isteğine nasıl hizmet ettiğini ve diğer ilişkilerini nasıl etkiliyor olabileceğini konuştuk. Berke geri bildirimimi kabul etti ve görüşmenin sonunda kendisini genel, soyut kavramlarla anlatmasının kendini baltalayan ve insanlar tarafindan anlaşılmayacağı yönündeki beklentisini gerçekleştiren bir tarafi olabileceği sonucuna vardk.

Duygularını dışa vurmayan danışanlarla çalı̧ırken McWilliams (1994) danışanlara tekrar tekrar duygularını sormanın bir güç mücadelesi yaratabileceğini söyler ve bunun yerine hayali, sembolik ve sanatsal iletişim yöntemlerini kullanarak terapiye duygusal bir boyut katabileceğimizi belirtir. Ben de entelektüel konuşmayı kırabilmek ve Berke'nin duyguları üzerindeki kontrolünü azaltabilmek için skç̧a metafor kullandım, ve hayal gücünün ve fantezilerinin ifadesini teşvik ettim. Örneğin, görüşmelerimizden birinde Berke gizli duygu, arzu ve fantezilerini "karanlık oda" olarak adlandırdı. Ondan bu odayı hayal etmesini ve detaylica bana anlatmasını istedim. Uzun süre kullandığımız bu metafor bize Berke'nin bastırılan istek ve duygularını kelimelere dökebilmesi için bir araç sağladı. Başka bir zaman, bana kontrolden çıkmaktan korktuğunu söylediğinde hayal gücünü kullanmasını ve kontrolü nasıl kaybedeceğini, neler yapacağını tarif etmesini istedim. Danışanı kendini açmaya davet ederken ona duygularının ve fantezilerinin yargılanmadığı, kabul edici bir ortam sunmanın da gerekli olduğuna inanıyorum. 'Karanlık oda"sını empati ve kabulle dinledikçe, saldırgan ya da dürtüsel isteklerini normalleştirdikçe inanıyorum ki bu, Berke'ye düzeltici bir deneyim (corrective experience) sağladı. Zaman içinde işbirliğimiz güçlendi ve uzun dönemde Berke ihtiyaçlarına daha az cezalandırıcı yaklaşarak ilişkilerde kendisini açmak konusunda daha cesur adımlar atmaya başladi.

Berke'nin bana yönelik olumsuz duygularını ifade etmesinin duygusal kısitlılı̆̆ını kırmada önemli bir adım olduğunu düşünüyorum. Bazen görüşmelere öfkeli geldiğinde ve insanların kendisini anlamadığını ifade ettiğinde bana yönelik benzer hisleri olup olmadığını merak ederdim. Birkaç kez direkt olarak sordum. Görüşmelerimizden birinde, duyguları kabul etmekten kaçındığıyla ilgili yaptığım yorumu takiben ses tonunun, duruşunun değiştiğini ve bana öfkelendiğini fark ettim. Fakat onu durdurup az önce ne olduğunu sorduğumda olumsuz bir duygunun varlı̆̆ını reddetti. Bir güç mücadelesine girmedim fakat bir sonraki görüşmemize önceki seans hakkında konuşarak başladım. Berke bana öfkelendiğini kabul etti ve anlaşılmamış hissettiğini söyledi. Önceki seans bana ne söylemek istemiş olabilece ğini sordum. İlk defa açıkça bana yönelik olumsuz duygu ve düşüncelerini paylaştı ve bunu memnuniyetle karşıladım. Safran ve Muran (2000) terapist danışanın öfkesine karşı bir atak gerçekleştirmediğinde bunun, danışanın saldırganlığın tehlikeli olduğuna yönelik inancını boşa çıkardığını söyler. Bu noktadan sonra, "perde" diye tanımladığımız Berke'nin duygu ifadelerini kısıtlayan engeller hakkında konuşmaya ve olumsuz duyguları nasıl ifade edebileceğine odaklanmaya başladı. Sonrasında perde, düşünce ve duyguların bloke edilmesini 
simgeleyen sıkça kullandığımız başka bir metafor haline geldi. Ayrıca, $100 \%$ anlaşılma beklentisinin ne kadar gerçekçi olduğunu konuştuk ve insanlarla duygu ve düşüncelerini paylaşmasının anlaşılma beklentisine yardımcı olabileceği fikrinden yola çıkarak davranışsal çalısmalar yaptık.

Newman (1994) danışanın terapinin gidişatında söz sahibi olmasına ve seçim yapmasına izin vermenin dirençle çalşsırken önemli bir admm olduğunu vurgular. Bu yöntem bize de terapötik ilişkiyi güçlendirmek ve danışanın işbirliğini arttırmak açısından yardımcı oldu. Örneğin bir görüşmemizde Berke smavlarda düşen başarısından yakındı ve terapide çok temel ve zor konuları ele aldığımız için zihinsel enerjisinin çoğunu bu konular üzerine düşünerek harcadığını sözlerine ekledi. Bu deneyimi üzerine daha detaylı konuştuktan sonra ona önümüzdeki birkaç seans okul performansıyla ilgili konuşarak o alanda neler olup bittiğine bakmak isteyip istemeyeceğini sordum. Berke buna şaşırdı ve bu gibi günlük konular hakkında konuşabileceğimizi bilmediğini söyleyerek teklifimi kabul etti. Sanıyorum ki buradaki önerim ona yaşadığg zorluğu anladığım, onayladığım ve otono misine saygı duyduğum mesajını verdi. Ayrıca, ihtiyacını onaylamam ve ona kontrol şansı vermem danışanın şemalarından kaynaklanan, insanların onu anlamayaca ğ ve dikkate almayacağına yönelik beklentileriyle de çelişmiş oldu.

Ahlaki akıl yürütme terapi çalşsmamızdaki en zor alanlardan biriydi. Leahy (2003) terapistin ahlak kurallarına karşı yaptığı vurgunun danışanları terapiden yabancılaştırabileceğini savunur. Bu sebeple ben de Berke'nin ahlaki bakışını ve diğer insanların ihtiyaçlarına olan hassasiyetini tanımaya ve saygı duymaya çalışım. Fakat bir yandan da ahlaki kurallarını kendine zarar vermeyecek, orantılı düzeye çekmeye çabaladım. Berke kontrol edemeyeceği durumlarda gerçekten ne kadar sorumluluk sahibi olduğunu sorgulamak için kullandığım bilişsel tekniklere karşı çıktı ve daha iyi bir dünya için olanlardan sorumlu olduğunu açikça belirtti. Neyse ki, ahlaki düşüncelerindeki iki uçluluğa işaret eden yorumlarıma karşı daha açiktı. Bu sebeple ona, sorumlulukla hareket etmenin kendine işkence etmeyi gerektirmediğini ve duyarsızca davranmak ile aşırı sorumluluk/suçluluk uçları arasında başka alternatifler de olduğunu göstermeye çahş̧ım. Buna rağmen ahlaki konulardaki katı kuralları ve üzerinde taşıdığı aşırı sorumluluk hissi terapiye en az cevap veren alanlar oldu.

Alexander $(1930,1946)$ ' a göre, terapinin iyileştirici gücü geçmişteki duygusal durumları ve olayları hatırlamaktan geçmez; travmatik olayları tamir eden şey, düzeltici deneyimdir (corrective experience, akt., Hartman \& Zimberoff, 2004). Ben de uyguladığım müdahalelerin çoğunluğunda en temel terapötik faktörün yeni bir ilişkilenme şeklinin getirdiği deneyimlerden kaynaklanan bir öğrenme olduğuna inanıyorum. Tedavi boyunca birkaç istisna haricinde Berke'nin ilişkilerle ilgili altta yatan şemalarının oluşturduğu beklentilerin aksine, bana atanan rolü (Messer, 2002) oynamadım. Bu rol, kontrol eden ve cezaland ran babasinin rolü idi. Bunun yerine ona, kendi ihtiyaçlarının peşinden gitmenin, saldırgan ve cinsel dürtülerin ifadesinin ve zayıflığın kabul edildiği yeni bir ilişki biçimi sunmaya çalışım. Bugün yaklaşı iki yıl süren terapi çalışmasının ardından Berke'nin terapi sürecine baktığımda, onun terapinin bitiminde daha spontane ve daha az kontrolcü olduğunu, duygularını ifade etme konusunda daha rahat olduğunu ve kendi kişisel ihtiyaçlarına karşı daha anlayışlı olduğunu söyleyebiliriz. Maroda (2010)'ya göre her danışanın, terapist değişimin yararlı olacağını söylese de, değişmek istemediği alanlar vardır. Berke hala yanlış anlaşıldığına yönelik ipuçlarına karşı hassas; fakat yanlıs anlaşılsa bile kendisini anlatabileceğini söylüyor. Hala ciddi ve rasyonel bir tarzı var, fakat ilk defa sonuçlarını düşünmeden arkadaşlarına şaka yapabildiğini söylüyor. Hala dünyayı değiştirmek için ahlaki açıdan sorumlu hissediyor fakat açık şekilde bu yönünü değiştirmek istemediğini belirtiyor. Onun seçimlerine ve kimliğine saygı duyuyorum ve Berke'nin geldiğimiz nokta ile ilgili dile getirdiği memnuniyetine de dayanarak bunun yeterince iyi bir sonlandırma (good enough termination; Gabbard, 2009) olduğunu düşünüyorum. 


\section{Sonuç}

Bu makalede, direnci kavramsallaştırmaya ve danışanlarımdan biri olan Berke'nin psikoterapi sürecini örnek vererek terapide dirençle nasıl çalşılabileceğini anlatmaya çalştım. Üzerinde durduğum temel konulardan biri direnci tanımlamamız, kavramsallaştırmamız ve onunla çalışmamızın teorik yaklaşımımızdan etkileneceği idi. Direnci terapide ortadan kaldırılması gereken bir engel olarak görmek yerine, direncin anlamını ve işlevini anlamanın, bu bilgiyi danışan problemlerinin formülasyonu ve tedavinin planlanmasında kullanmanın önemini vurguladım. Bunun yanında direncin her zaman danışandan kaynaklanmayabileceğini, terapistten kaynaklanan süreçlerin de dirence katkı sağlayabileceğini ve terapistin kendi katkısını analiz etmesinin öneminin altını çizdim.

Berke'nin tedavi sürecinin bize dirençle ilgili bazı kavrayışlar sağladığını umuyorum. Berke'nin yoğun şekilde kullandığı entellektüelizasyon, duygularını yalitması, sıkça başvurduğu ahlaki akıl yürütme ve ilişkilere dair geçmişten gelen şemaları terapi çalışmasında yol kat etmemizde bir zorluk yaratmaktaydı. Terapist olarak ben de entellektüelizasyonu farkında olmadan besleyerek ve Berke'yle bir güç mücadelesine girerek dirence katkı sağlamaktaydım. Berke'nin ilişkilenme ve kendini ifade etme tarzını onun kişilik organizasyonunun bir parçası ve bir baş etme biçimi olarak görmeye başlamam terapi sürecinde bir kırılma noktası oluşturdu. Ona güvenli, kabullenici bir ortam sağlamak, terapi kararlarında ona aktif bir rol vermek, öfke gibi olumsuz duygularının ifadesini teşvik etmek, kendini baltalayıcı örüntüleriyle yüzleştirmek ve doğru noktalarda kendimi açmamın sonucunda terapi amaçlarımıza büyük ölçüde ulaştığımızı, bunu yaparken dirence karşı değil, dirençle birlikte çalş̧tı̆̆ımızı düşünüyorum. 


\section{Kaynaklar}

Arkowitz, H. (2002). Toward an integrative perspective on resistance to change. Journal of Clinical Psychology, 58(2), 219-227.

Basch, M.F. (1982). Behavioral and psychodynamic psychotherapies: Mutually exclusive or reinforcing? In P.L. Wachtel (Ed.), Resistance: Psychodynamic and behavioral approaches (pp. 187196). New York: Plenum.

Beck, A.T., Freeman, A., Davis, D.D., \& Associates (2004). Cognitive therapy of personality disorders. (2nd edition). New York: Guilford.

Björklund, F. (2000). Defense mechanisms and morality: A link between isolation and moralization. Scandinavian Journal of Psycholology, 41(1), 55-61.

Bischoff, M. M., \& Tracey, T. J. G. (1995). Client resistance as predicted by therapist behavior: A study of sequential dependence. Journal of Counseling Psychology, 42(4), 487-495.

Burns, D. D. (1999). Feeling good: The new mood therapy. New York: Quill.

Butler, M. H., \& Bird, M. H. (2000). Narrative and interactional process for preventing harmful struggle in therapy. Journal of Mental and Family Therapy, 26, 123-142.

Dryden, W., \& Neenan, M. (2011). Working with resistance in Rational Emotive Behaviour Therapy: A practitioner's guide. Routledge: East Sussex.

Dewald, P. A. (1982). Psychoanalytic perspectives on resistance. In P.L. Wachtel (Ed.), Resistance:

Psychodynamic and behavioral approaches (pp. 45- 68). New York: Plenum.

Ellis, A. (2002). Overcoming resistance: A rational emotive behavior therapy integrative approach. New York: Springer.

Engle, D., \& Holiman, M. (2002). A gestalt-experiential perspective on resistance. Journal of Clinical Psychology, 58(2), 175-83.

Fenichel (1946). The psychoanalytic theory of neurosis. London: Routledge and Kegan Paul.

Gabbard, G. O. (2009). What is a "good enough" termination? Journal of American Psychoanalytic Association, 57, 575-594.

Hartman, D., \& Zimberoff, D. (2004). Corrective emotional experience in the therapeutic process. Journal of Heart-Centered Therapies, 7(2), 3-84.

Holmes, C. A. V.(2005). The paradox of countertransference: You and me, here and now. New York: Palgrave Macmillan.

Maroda, K. (2010). Psychodynamic techniques: Working with emotion in the therapeutic rela-tonship. New York: Guilford.

McWilliams, N. (1994). Psychoanalytic diagnosis: Understanding personality structure in the clinical process. New York: Guilford Press.

Meichenbaum, D., \& Gilmore, J. B. (1982). Resistance from a cognitive-behavioral perspective. In P. L. Wachtel (Ed.), Resistance: Psychodynamic and behavioral approaches (pp. 133-156). New York: Plenum Press.

Messer, S. B. (2002). A psychodynamic perspective on resistance in psychotherapy: vive la résistance. Journal of Clinical Psychology, 58(2), 157-163.

Mitchell, S. A., \& Black, M. J. (1995). Freud and beyond: A history of modern psychoanalytic thought. New York: Basic Books.

Newman, C.F. (1994). Understanding client resistance: Methods for enhancing motivation to change. Cognitive and Behavioral Practice, 1, 47-69.

Newman, C.F. (2002). A cognitive perspective on resistance in psychotherapy. JCLP/In Session: Psychotherapy in Practice, 58(2), 165-174.

King, S. M. (1992). Therapeutic utilization of client resistance. Individual Psychology, 48(2), 165-174. 
Lampropoulos, G. K. (2001). Bridging technical eclecticism and theoretical integration: Assimilative integration. Journal of Psychotherapy Integration, 11, 5-19.

Lazarus, A. A., \& Fay, A. (1982). Resistance or rationalization? A cognitive-behavioral perspective. In P. L. Wachtel (Ed.), Resistance: Psychodynamic and behavioral approaches (pp. 115-132). New York: Plenum Press.

Leahy, R. L. (2003). Overcoming resistance in cognitive therapy. Guilford: New York

Lorand, S. (1967). Clinical and theoretical aspects of resistance. Psychotherapy and Psychosomatics, 15(2):162-178.

Otani, A. (1989). Client resistance in counseling: Its theoretical rationale and taxonomic classification. Journal of Counseling and Development, 67, 458-46.

Patterson, C. H. (2000). Understanding psychotherapy: Fifty years of client-centered theory and practice. Ross-on-Wye: PCCS Books.

Safran, J. D., \& Muran, J. C. (2000). Negotiating the Therapeutic Alliance: A Relational Treatment Guide. New York: The Guilford Press.

Schlesinger, H.J. (1982). Resistance as process. In P.L. Wachtel (Ed.), Resistance: Psychodynamic and behavioral approaches (pp. 25-44). New York: Plenum.

Silverberg, F. (1990). Working with resistance. Journal of Contemplative Psychotherapy, 7, 21-34.

Sultanoff, S. M. (2013). Integrating humor into psychotherapy: Research, theory, and the necessary conditions for the presence of therapeutic humor in helping relationships. The Humanistic Psychologist, 41, 388-399.

Turkat, I. D., \& Meyer, V. (1982). The behavior-analytic approach. In P.L. Wachtel (Ed.), Resistance: Psychodynamic and behavioral approaches (pp. 157-184). New York: Plenum.

Wachtel, P. L. (Ed.) (1982). Resistance: Psychodynamic and behavioral approaches. New York: Plenum.

Watson, J. C. (2006). Addressing client resistance: Recognizing and processing in-session occurrences. Retrieved October 22, 2014 from http:/counselingoutfitters.com/Watson.

Wessler, R., Hankin, S., \& Stern, J. (2001). Succeeding with difficult clients: Applications of cognitive appraisal therapy. New York: Academic Press.

Yalom, I. D. (1980). Existential psychotherapy. New York: Basic Books.

Young, J.E., Klosko, J.S., \& Weishaar, M. (2003). Schema therapy: A Practitioner's guide. New York: Guilford Publications.

Zepf, S. (2011). About rationalization and intellectualization. International Forum of Psychoanalysis, 20, 148-158. 


\section{Summary \\ Understanding and Working Through Resistance in Psychotherapy}

The term resistance has a variety of definitions based on different therapy approaches; but it briefly indicates an opposition to change in psychotherapy. The term resistance was first used by the psychoanalytic model in the early 1900s. Today, it is possible to find as many models of resistance as the theories of psychotherapy. It is necessary to understand resistance because it is a fact of every clinical situation; that is there is always a certain amount of client opposition in psycho-therapy; and resistance affects the treatment outcome.

Traditionally, resistance has been viewed as a characteristic of the client and seen as an obstacle to treatment. However, there has been a major change in how we view resistance today. As opposed to the early view that resistance stems from the client, recent conceptualizations of resistance take into account the mutual role of both the client and the therapist. Thus, resistance is seen as a relational and two-person phenomenon rather than a negative client characteristic. Parallel to this change, therapists are encouraged to explore their own contribution to resistance and work on their own emotions towards clients which are not helpful in the treatment process. Furthermore, the traditional view of resistance as a roadblock to psychotherapy has shifted to-wards a more positive view of resistance which emphasizes the richness of information re-sistance provides about clients and us as therapists, as well as the adaptive functions resistance may serve for clients. So, resistance is now seen as a source of information to guide case formulation and interventions designed specifically for that client. Additionally, it is now believed that resistance may not necessarily be dysfunctional. In some cases what we call resistance might be clients' best available and adaptive strategy to resolve problems.

In this paper, after a brief review of the definition and theoretical models of resistance, a case example will be used to discuss the conceptualization of resistance and working through resistance in psychotherapy. Based on the psychotherapy work with this case, the author will out-line the sources of resistance, as well as specific interventions she used to facilitate working to-wards the treatment goals. The author will highlight the importance of understanding the mean-ing and function of resistance in the psychotherapy process, the therapist's responsibility to ana-lyze his/her contribution to resistance, and working through resistance rather than working against it.

Keywords: resistance, psychotherapy, case study 